\title{
Intellectual Capital, Entrepreneurial Strategy and New Ventures Performance: Mediating Role of Com petitive Advantage
}

\begin{abstract}
Muhammad Anwar', Sher Zaman Khan ${ }^{2}$, Najib Ullah Khan ${ }^{3}$
Abstract

In dynamic markets, newly established ventures look for competitive strategies and skills to ensure their survival and to avoid failure. This paper examines the influence of venture internal capabilities including intellectual capital and entrepreneurial strategy on new venture performance by using competitive advantage as a mediator. We collected data from 227 ventures through a structured questionnaire in addition to interviewing 17 entrepreneurs. The findings of the study indicate that intellectual capital, entrepreneurial strategy and competitive advantage have a significant positive influence on new venture performance. Similarly,intellectual capital and entrepreneurial strategy significantly positively contribute to competitive advantage. Furthermore, competitive advantage fully mediates the relationship between intellectual capital and new venture performance as well as it plays a partial mediating role in the relationship between entrepreneurial strategy and new venture performance. The results suggest that the aforementioned internal capabilities play a significant role in new venture success which might be beneficial for owners and managers to achieve competitive position in a turbulent market.
\end{abstract}

Keywords: Intellectual capital, entrepreneurial strategy, competitive advantage, new venture performance.

\section{Introduction}

Strategic management's scholars look for an answer "why firms perform differently". Existing literature has realized that firms can gain competitive advantage (CA) and superior performance by using resources efficiently and innovatively (Anwar, 2018; Demil, Lecocq, Ricart, \& Zott, 2015; Shane \& Venkataraman, 2000; 220). However, in the current era, market changes occur beyond the expectations (Brizek, 2014) and

1 Research Associate, International Islamic University Islamabad, Pakistan.

Email:m.anwar.ims@gmail.com

2 PhD Scholar, University of Science Technology Beijing, China.

3 PhD Scholar, Beijing University of Technology, China. Email: Najibkhanbs18@yahoo.com

\begin{tabular}{lll} 
ARTICLE HISTORY & & \\
7 Aug, 2017 Submission Received & 1 Oct, 2017 & First Review \\
\hline 24 Oct, 2017 Revised Version Received & 19 Dec, 2017 & Second Review \\
\hline 27 Dec, 2017 Revised Version Received & 15 Jan, 2018 & Accepted
\end{tabular}


firms (especially new ventures) have to cope with such dynamic markets and future demands (Sun, Yao, Zhang, Chen, \& Liu, 2016). They need unique strategic posture, either, looking for a new product development or entry into a new market. Many firms typically never plan to react a new opportunity in time, they react but too late, or even always follow their counterparts (Meyer \& Heppard, 2000, p. 7). However, firms, particularly, small and medium enterprises (SMEs) have might not only focus on market changes and demands but also have to strengthen their internal capabilities such as intellectual capital (IC) and entrepreneurial strategy (ES) that significantly influence their CA and performance (Gruber-Muecke \& Hofer, 2015; Jurczak, 2008; Kantur, 2016). Firms' internal capabilities and strategic comportments greatly affect their performance as compared to external influences (Covin \& Slevin, 1989).

A firm pursuing ES requires human capital and an effective organizational system to monitor information, exploitation of new market opportunities and the combination of resources in order to gain higher profitability (Meyer \& Heppard, 2000; Stam \& Elfring, 2008). Table 2 depicts the basic concepts and various dimensions of ES. Existing studies have documented the major aim of ES as to gain firms' CA and success (Demil et al., 2015; Obeng, Robson, \& Haugh, 2014; Priem, 2007). Specifically, in emerging markets, minor attention has been given to the importance of IC, ES in new venture performance (NVP) and CA. It is argued that majority of SMEs are failed due to lack of human skills in developed and emerging economies. In Pakistan, there is a great need for such studies to ensure the survival of SMEs (Majid \& Yasir, 2017). In addition, newly established ventures are underemphasized in prior literature. This study grasps potential advantages for managers and entrepreneurs in order to ensure the sustainability of newly established ventures. Motivated by this fact as well as by Covin and Slevin (1989) and Gruber-Muecke and Hofer (2015) who argued that a firm's internal capabilities have more influence on performance over its external capabilities. This study aims to investigate the determinants associated with the survival of new ventures by using its core internal capabilities. In addition, this study fills the research gap by using a mediating role of CA between IC-NVP and ES-NVP that is remained scared in prior studies.

SMEs play a pivotal role in injecting a country's GDP (Khattak, Arslan, \& Umair, 2011; Rahayu \& Day, 2015). The definition of SMEs varies across the world. Mainly, SMEs are defined on the basis of three major factors: a number of employees, total assets possessed and annual sales/turnover. Table1 shows major definitions of SMEs across the globe.

The core objective of the study is to check the impact of IC and ES on CA and NVP and also the mediating role of CA between IC and NVP and ES and NVP in a developing country Pakistan. The study is equally beneficial for owners, executives 
Table 1: Definitions of SMEs

\begin{tabular}{|c|c|c|}
\hline Defined By & Max. No. of Employees & Max.Annual Sale/Turnover \\
\hline SBP Pakistan $^{1}$ & 250 & Rs.75-800million \\
\hline SMEDA(Pakistan) $^{2}$ & 250 & Rs.250million \\
\hline World Bank $^{*}$ & 300 & $\$ 15$ million \\
\hline MIF-IADB $^{*}$ & 100 & No limit \\
\hline
\end{tabular}

$1 \mathrm{SBP}=$ State Bank of Pakistan further classified SMEs as manufacturing, trading, and services. Enterprises which have employees' up-to 20-50 with annual sales turnover up to Rs. 150 million are placed into the services business. Enterprises with 50-100 employees are put into trading and enterprises with more than 50 and less than 250 employees with annual sales turnover more than Rs. 175 million and Less than Rs.800 million are considered as manufacturing.

2SMEDA=Small and Medium Enterprises Development Authority developed by Govt. of Pakistan in October 1998. It started formal policies and programs for SMEs development and growth almost in 2006 and 2007.

*Multilateral Investment Bank-Inter-American Development Bank.

and top managers of SMEs who invest numerous resources into risky projects and tangible assets that can cause a big loss of investment and wastage of time.

Pakistan is a developing country of the world. Majority of businesses are SMEs which contribute more than 30\% to GDP of Pakistan (Akhtar, Ismail, Hussain, \& Umair-ur-Rehman, 2015). However, there are numerous problems faced by SMEs in the country that decline their survival and performance (Shah, Gul, \& Aziz, 2011). On the Index of Ease of Doing Business (IEDB) perspective, Pakistan has ranked at $144^{\text {th }}$ number out of 190 countries (World Bank, 2017). According to Khawaja (2006- CEO of SMEDA), 19\% of newly established ventures have less than 5 years life and only $4 \%$ of firms survive up to 25 years in Pakistan. These arguments give alarming signals to academician and researchers to explore the major causes of new venture' success and failure.

This study answers the questions "Do IC and ES impact CA and NVP"? and "does CA mediate the relationship between IC and NVP as well as the relationship between ES and NVP?". The present study highlights the importance of firms' intangible assets (IC \& ES) that lead firms towards CA and superior performance. The same theme can be observed by Resource Base View Theory (RBVT) that firms' internal capabilities contribute more significantly toward superior performance as compared to external capabilities (Barney, 1991). This study also claims to underpin the theme of RBVT in terms of firms' internal capabilities including IC, ES, and CA. 


\section{Literature Review and Theoretical Background}

The literature review section of the study is organized in the following shape. The first section describes the concepts of IC, ES, and NVP. The second part is underpinning the theoretical background and the third part consists of the hypotheses development.

\subsection{Intellectual capital}

According to Saint-Onge (1996), there are three main elements of IC: (a) Human Capital refers to the capabilities of owners and employees that tend to provide support and solution to customers. (b) Customer Capital refers to the gravity, girth, attachment, and profitability from customers. (c) Structural Capital describes the competencies of an organization to meet the market needs.

\subsection{Entrepreneurial strategy}

Entrepreneurial strategy (ES) can be measured with several dimensions. However, in case of newly established ventures, the strategy is recommended to be associated with innovativeness, risk-taking, and proactivity approaches. Lumpkin and Dess (1996) formally demonstrated three kinds of entrepreneurial strategies and termed as "entrepreneurial orientation".

- Innovativeness: supporting and inspiring new-fangled ideas as well as investigation and creativity.

- Risk taking: The degree to which owners and managers of the firms are willing to take a risk and make great resources commitments. Definitely, those commitments which have a sensible chance of costly failures.

- Proactiveness: strives for novel opportunities which may or may not be allied to the existing line of operations.

Table 2 provides concepts about ES approached in newly established ventures.

\subsection{New venture scope and definition}

A venture is considered new if it is not yet matured. However, when a firm is called to be matured is not yet clearly determined (Chrisman, Bauerschmidt, \& Hofer, 1998). Though, the time when a new venture enters into a maturity phase varies and typically depends on the industry, resources, and strategy. A firm may become mature in 3 to 5 years (Biggadike, 1979). But frequently the time ranges from 8 to 12 years because of preliminary regulations and setup. Hence, in this study, we targeted 
Table 2: Entrepreneurial Strategies Concepts

\begin{tabular}{|c|}
\hline $\begin{array}{c}\text { Entrepreneurial strategies are defined with different aspects in the prior literatures. However, } \\
\text { we give some of the key explanations of entrepreneurial strategy related to new firms' sustainable } \\
\text { CA; }\end{array}$ \\
\hline $\begin{array}{c}\text { 1. Meyer and Heppard (2000): Entrepreneurial strategy generates economic values for a firm. It pri- } \\
\text { marily focuses on internal characteristics of a firm such as innovativeness, creativity and decision's } \\
\text { responsibility etc. rather than on more complex notion of dynamic competitive strategies }\end{array}$ \\
\hline $\begin{array}{c}\text { 2. Demil et al. (2015): Entrepreneurial strategy in today's business focuses on more modern factors } \\
\text { and genuine tactics such as to exploit an opportunity, innovation and strategic planned behaviors } \\
\text { unlike traditional resource based view strategy that is criticized to explicate what make resources } \\
\text { valuable. }\end{array}$ \\
\hline $\begin{array}{c}\text { 3. Russell and Russell (1992): Entrepreneurial strategy where members of firms focus on day-to-day } \\
\text { efforts to produce a stream of innovation. Successful entrepreneurial strategy is related to firms' } \\
\text { innovative activities and resource allocation that would create and add value to firms. }\end{array}$ \\
4. Mintzberg (1993): Entrepreneurial strategies are to be process oriented, that's why these strategies \\
focus on innovation and aim to excite innovation constructing behavior. \\
\hline 5. Murray (1984): A strategy through which firms establish and re-establish their \\
\hline
\end{tabular}

ventures that have started their operation during last 10 years.

\subsection{Underpinning theory}

According to the Resource-Based View Theory (RBVT), firms have unique resources, capabilities, and knowledge which help them to formulate unique strategies in order to get "effectiveness and efficiency" (Barney, 1991).

IC deems to be a resource that can be underscored in intangible resources possessed by firms that are unambiguously linked to an organization's strategy (Rossi, Cricelli, Grimaldi, \& Greco, 2016). For instance, IC refers to firms' intangible assets, groundwork, human-centered and intellectual belongings that lift firms and assist the smooth functioning of an organization (Brooking, 1996). Thus, IC contains all the intangible assets (e.g. capabilities, attributes and processes, information and knowledge etc.) that jointly contribute and boost firm's efficiency and sustainable CA (Barney, 1991). Major aims of IC are going around a firm's values and performance in terms of intangibility. It is considered as a less risky resource toward firm' value creation in emerging markets (Chahal \& Bakshi, 2015; Khalique, Bontis, Shaari, \& Isa, 2015).

Typically, RBVT enhances sustainable CA and superior performance by using the two main capabilities (a) dynamic capabilities and (b) adaptive capabilities. Dynamic capabilities support organizations to acquire sustainable CA by using internal skills (i.e. human capital, knowledge $\&$ information etc.) to amend resources to respond to 
market changes (Day, 2014). Adoptive capabilities encourage organizations to enhance their superior performance and sustainable CA while responding to market revolution, heroic act to an opportunity and seize the customer demands proactively. When organizations have readiness for novel markets and act as a "first mover" in different phases, they adore success. In addition, the readiness for external market situations becomes possible when organizations have innovative orientations (Day, 2014). Simply, dynamic capabilities pertaining to the efforts practiced by firms to respond to the changes at a proper time. For this purpose, firms may use ES to give a response to the changes effectively. Adoptive capabilities characterized firms' proactive behavior to respond to changes earlier than industry rivals or competitors. This pertains to firms' proactive behavior and strategic approaches practiced for market situations. Thus, the two capabilities mainly approach firm's internal skills (IC \& ES) connected to external market conditions and demands. As aforementioned, the importance of ES cannot be underestimated in terms of NVP (Covin \& Slevin, 1989; Lumpkin \& Dess, 1996) because new ventures have lack of resources and seek opportunities by using EO skills (Lumpkin \& Dess, 2001). It is argued that IC has a significant relationship with ES in the context of sustainable CA and superior performance. Because IC promotes entrepreneurial activities that may help to enhanc firm's value.

We interpret firms' internal capabilities as IC and ES that can be practiced by SMEs for the purpose to gain superior performance. These capabilities are deemed to be firms' core intangible resources that provide sustainable CA and superior performance over rival firms and competitors (Lonial \& Carter, 2015; Shirokova, Vega, $\&$ Sokolova, 2013). However, the capabilities are not indispensable to be practiced exclusively but many firms perform it jointly to cope with the market changes.

\subsection{Hypotheses development}

\subsubsection{Intellectual capital and new venture performance}

IC is considered as a key driver of NVP. Higher the firm's level of intellectual capabilities, better will be its performance in markets (Harris \& Moffat, 2013). Successful firms have observed the importance of IC such as knowledge, human capital and relational because in the current era, these factors found to be significantly related to firms' performance (Muhammad \& Ismail, 2009). IC has a significant role in SMEs' performance because SMEs have limited resources to invest in tangible assets, thus they focus on IC to achieve superior performance and profitability (Cleary \& Quinn, 2016). Currently, IC, being an intangible asset is assumed to have greater value than tangible assets (Agostini, Nosella, \& Filippini, 2017). Each dimension of IC such as human capital, customer capital and structure capital significantly influences firm's performance such as efficiency, profitability, productivity and market performance 
(Tandon, Purohit, \& Tandon, 2016). Particularly, in emerging markets like Pakistan, firms having higher IC, enjoy superior profit over those having low level of IC (Ahmad $\&$ Ahmed, 2016), because SMEs in the country have lack of resources, thus IC plays crucial rule in the successful survival of firms (Khalique et al., 2015). Therefore, we posit hypothesis:

H1. Intellectual capital has a positive relationship with new venture performance.

\subsubsection{Entrepreneurial strategy and new venture performance}

ES has been discussed with several aspects and the strategic posture of a firm varies with stages of the industry life cycle. For instance, newly established firms focus on innovative, risk-taking and proactiveness strategies to grow up. When firms capture a maturity phase, they follow conservative approaches such as risk aversion and reactive strategies (Covin \& Slevin, 1990; Demil et al., 2015; Falbe, Dandridge, \& Kumar, 1999). Especially, new ventures tend to have more entrepreneurial approaches, because they have lack of resources and seek higher performance by using entrepreneurial orientation (Lumpkin \& Dess, 2001). ES is an entrepreneurial dominant logic that searches persistent information for innovation and new product ideas which in turn lead higher profitability (Meyer \& Heppard, 2000).

Lumpkin and Dess (1996) presented three major entrepreneurial strategies. Innovativeness is a strategic weapon by which a firm deals with variation in the internal and external marketplaces. In order to survive in competitive atmospheres, it is vital to fuel innovativeness which in turn contributes to competitive superiority and firm's performance (Hult, Hurley, \& Knight 2004). Risk taking is essential for owners and managers in order to compete in turbulent markets. To acquire high profit by entering into a new territory or new product developments, firms must be risk takers otherwise they cannot compete in a turbulent market (Zahra, Hayton, Marcel, \& O'Neill, 2001). Proactive ventures are the "first movers" and enter into markets ahead of their competitors, thus they settle a competitive position in the markets, seize higher return and profitability in comparison with their main competitors (Wiklund \& Shepherd, 2005). Particularly, in developing countries, ES has a greater importance because it leads firms to raise and survive (Obeng et al., 2014). Studies of this nature have concluded that ES (innovativeness, risk-taking $\&$ proactiveness) has a positive impact on firms' performance (Lumpkin \& Dess, 1996, 2001; Obeng et al., 2014). Therefore we hypothesize as:

H2. The entrepreneurial strategy has a positive relationship with new venture performance

2.5.3 Intellectual capital and competitive advantage

Contrary to large firms, SMEs have more potentials to obtain CA through the 
efficient use of the dimensions of IC (Chen, 2008). To be more innovative and competitive in dynamic markets, SMEs are required to use IC in an efficient way because, it plays a significant role in SMEs success (Chahal \& Bakshi, 2015; Todericiu \& Stlniป, 2015). In the early stage of venture creation and operation, firms need several internal capabilities to succeed in markets. Hence, IC in the first stage plays a crucial role in the success of firms (Hormiga, Batista-Canino, \& Sánchez-Medina, 2011). IC contributes to the success and growth of every kind of firms either small, medium or large. However, it is considered as a fundamental element of the success and CA of SMEs (Rossi et al., 2016). In the emerging market Pakistan, IC makes a significant contribution in the survival and growth of SMEs (Majid \& Yasir, 2017) and deems to be a necessary factor for public and private sector organizations (Khan \& Jamal, 2013). It is a big predictor as well as it has a significant impact on CA (Tandon et al., 2016; Yaseen, Dajani, \& Hasan, 2016). Therefore we propose a hypothesis:

H3. Intellectual capital has a positive relationship with a competitive advantage.

\subsubsection{Entrepreneurial strategy and competitive advantage}

In today's business, ES focuses on emerging factors and realistic approaches, such as exploitation of opportunities, innovation and strategically planned behavior, unlike traditional strategic approaches that have been criticized to explain what make resources valuable (Demil et al., 2015; Priem, 2007).

Successful ES related to a firm's innovative activities and resource allocation that would create innovation and add value to firms (Russell \& Russell, 1992). Firms strive to gain CA through new resources combination (innovation) by encompassing persistent and sanctioned pattern of an organization that simply refers to ES (Russell \& Russell, 1992, p. 640). To stay competitive in an environment, firms might be innovative (Herrera, 2015; Nouman, Taj, \& Gul, 2017).

All the dimensions of entrepreneurial strategic posture (innovativeness, risk-taking \& proactiveness) have a significant impact on firms' CA (Lechner \& Gudmunsson, 2014). For instance, innovation is one of the most significant factors through which a firm can get sustainable CA (cost leadership \& differentiation based) in a volatile market (Crossan \& Apaydin, 2010; Lechner \& Gudmunsson, 2014). Risk taking is needed for innovativeness and development of novel products and processes (Baker \& Maner, 2008). Proactiveness is essential for differential advantage. It provides the first mover benefit to firms (Lechner \& Gudmunsson, 2014). Entrepreneurial strategic behaviors (opportunity seeking $\&$ advantage seeking etc.) lead enterprises towards wealth creation (Hitt, Ireland, Camp, \& Sexton, 2001). Therefore, we posit hypothesis:

H4. The entrepreneurial strategy has a positive relationship with a competitive advantage. 


\subsubsection{Competitive advantage and new venture performance}

In the strategic management literature, CA and NVP are the two different constructs that are significantly positively related to each other (Ma, 2000; Ndofor, Sirmon, \& He, 2011). SMEs are insistently engaged in achieving CA over rivals. For this purpose, they adopt and formulate different strategies and risky processes, because they intend that CA leads firms toward success in a market (Cater \& Pucko, 2005; Palmer, Wright, \& Powers, 2015). Many firms pursue CA, for instance, some firms decrease their expenditure on production (cost leadership strategy) while increase expenditure on other activities to gain CA and a stronger position in markets (Radaev, 2002). Firms pursuing differentiation strategy, produce distinctive products which are perceived by customers as unique, so they purchase their products rather than favoring competitors' products. Similarly, some firms follow cost leadership strategy to reduce different types of costs related to product development, thus customers purchase the products in bulk which in turn leads to higher profitability (Porter, 1980). Firms' CA has a positive and significant impact on performance (Herzallah, Gutierrez, \& Rosas, 2014; Lechner \& Gudmunsson, 2014). Thus:

H5. Competitive advantage has a positive relationship with new venture performance.

2.5.6 Competitive advantage as a mediator between intellectual capital and new venture performance

IC is vital for business development, growth and is an important source for shareholders value creations. It is considered as a strategic asset that enables firms to gain a sustainable CA which in turn results in superior performance (Nardo \& Veltri, 2014). SMEs gain CA and increase values by using IC. Having higher level of IC, SMEs can create maximum customer values and positive image for their products and services, thus they establish long-term relationship with society and customers, which in turn leads toward greater performance (Jain, Vyas, \& Roy, 2017). Moreover, it is contended that IC does not directly impact performance, but firm's internal strategic posture and CA mediate the relationship (Kianto, Andreeva, \& Pavlov, 2013; Talebi, Rezazadeh, \& Najmabadi, 2015). In the same nature, some studies have argued that IC is a set of intangible assets and resources to help firms to build CA which in turn provides the benefit of higher performance and profitability (Berzkalne \& Zelgalve, 2014; Jain et al., 2017). Thus, we propose a hypothesis as:

H6. Competitive advantage mediates the relationship between intellectual capital and new venture performance

2.5.7 Competitive advantage as a mediator between entrepreneurial strategy and new venture performance 
As discussed earlier that new ventures undertake entrepreneurial activities: innovativeness, risk-taking and proactiveness strategies for the purpose to gain CA and superior performance (Covin \& Slevin, 1990). Products and services based on the entrepreneurial strategic posture such as innovativeness and proactiveness are perceived by customers as new and unique, so they purchase the products in bulk which facilitates firms to obtain a competitive position in the markets which results in higher financial performance (Lechner \& Gudmunsson, 2014). ES helps firms to stabilize their position and it enhances profit and revenue growth of firms even in declining industry (Burpitt \& Fowler, 2007). CA plays a mediating role between firm's performance and entrepreneurial dimensions such innovativeness, risk-taking and proactiveness (Mahmood \& Hanafi, 2013). In addition, prior studies have also argued that ES strengthens the relationship between EO and firm's performance (Brouthers, Nakos, \& Dimitratos, 2014) and between firm's internal process and financial performance (Huo, Qi, Wang, \& Zhao, 2014). Moreover, differentiation based advantage positively whereas, cost-based advantage negatively moderate the relationship between ES and firms performance (Su, Guo, \& Sun, 2017). Firms with higher entrepreneurial behavior tend to build and develop strategies which impact their performance (Moreno \& Casillas, 2008, p. 510). Therefore, we propose a hypothesis:

H7. Competitive advantage mediates the relationship between entrepreneurial strategy and new venture performance

\section{Methodology}

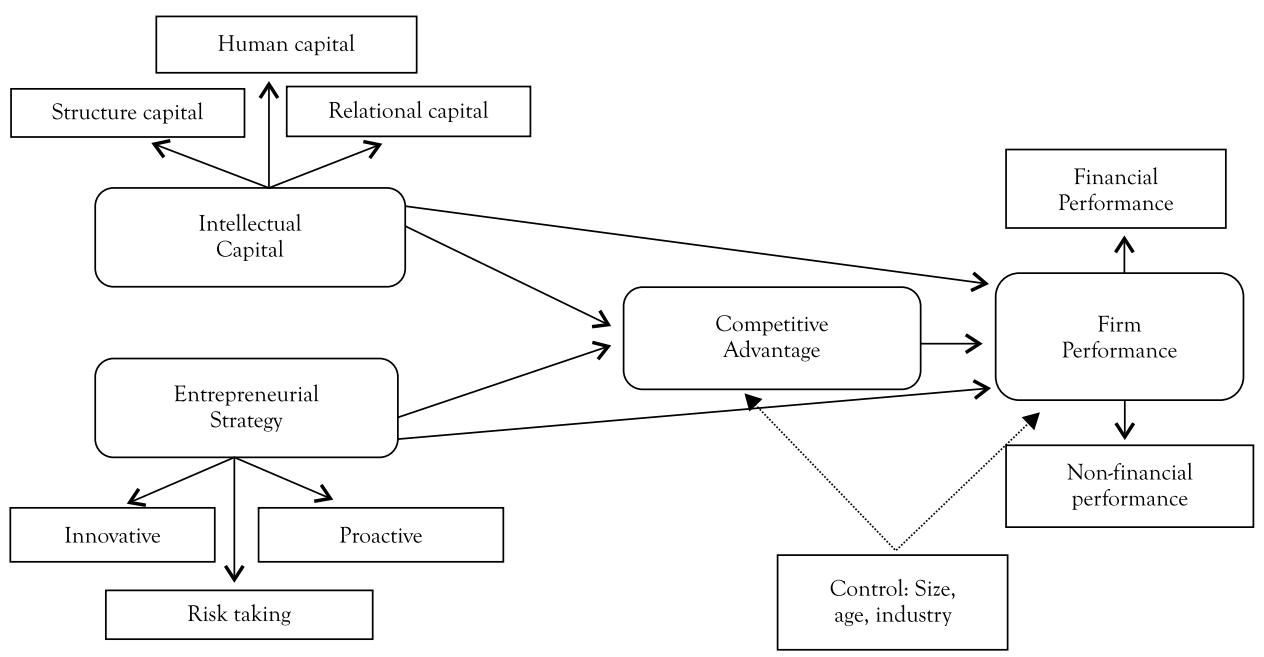

Figure 1: Theoretical Framework of the Research 


\subsection{Sam ple and data}

For this research, we collected data from SMEs located in the two big cities of Pakistan; Rawalpindi and Islamabad. The lists of newly established ventures were taken from Rawalpindi Chamber of Commerce and Industry (RCCI) and Islamabad Chamber of Commerce and Industry (ICCI). A self-reported questionnaire was used to collect data from owners and top managers of the new ventures because they are more familiar with their firms' strategies and performance (Tajeddini \& Mueller, 2012). The present study focused on new ventures established since last 10 years.

\subsection{Mix method approach}

This study followed a mixed approach (i.e. explanatory sequential) to articulate the results in a better way. Mixed method approach is more appropriate in entrepreneurship studies (Hohenthal, 2006) because it increases the validity of a research model and gains more mysterious understanding of the phenomena (Dana \& Dana, 2005; Jick, 1979). For instance, in this study, a structured questionnaire was used for data collection and interviews were conducted with 17 entrepreneurs. We used a hardcopy approach to collect data because an email survey provides a lower response rate comparatively, especially, in the emerging markets like Pakistan.

After distribution of 600 questionnaires among owners and managers of SMEs in Islamabad and Rawalpindi ( 300 each city), we received back 251 questionnaires (104 from Rawalpindi and 123 from Islamabad). However, some of these questionnaires have missed values and few of them were incorrectly filled, so 24 questionnaires were excluded from the final analysis and total 227 usable questionnaires were included for the analysis, showing an effective response rate $37.8 \%$. The data are cross-sectional in nature as collected in 1-month duration.

\subsection{Measures}

\subsubsection{Dependent variable}

New venture performance: This study used two aspects of firms' performance (financial performance and non-financial performance). Financial performance covers the firms' financial capability and growth such as return on assets, return on investment and profitability etc. Non-financial measures related to the customers and employees satisfaction as well as a market reputation etc. We used self-reported measures for NVP because SMEs are reluctant to provide their financial data and they are not bound to publish their financial information to the general public (Dibrell, Craig, $\&$ Neubaum, 2014). Moreover, self-reported measures provide more reasonable and adequate picture of firms' performance in emerging markets such as China and India 
etc. (Semrau, Ambos, \& Kraus, 2016). In this study, we used 10 items to measure NVP (financial performance $\&$ non-financial performance) adopted from a previous study (Prieto \& Revilla, 2006). Firms were asked to rate their performance on the basis of 10 items relative to their major competitors and industry rivals since last three years.

\subsubsection{Independent variables}

Intellectual Capital: IC covers human capital, structure capital and relational capital in strategic management literature. In this paper, we adopted IC measures from a previous study by Kianto et al. (2013). We used 6 items for IC and the sample items indicate "our firm's knowledge and competencies are evaluated persistently" and "our firm has a clear view of core knowledge" etc.

Entrepreneurial strategy: Successful ES requires "an effective management innovation process” (Russell \& Russell, 1992). The present study used nine items of ES adopted from the previous studies (Covin \& Slevin, 1990; Lumpkin \& Dess, 1996; Semrau et al., 2016). Particularly in new ventures, ES focuses on innovative ideas, proactive and risk-taking activities that lead the ventures toward sustainability and success.

\subsubsection{Mediator}

Competitive advantage: Prior studies operationalized CA with different dimensions. However, the most frequently used measures of CA are differentiation based and cost leadership based advantage (Porter, 1980). Development of unique products and services or adding new features to the existing products typically give a differentiation-based advantage. However, reducing products and services prices, minimizing operational and marketing cost provide cost-based advantage (Porter, 1980). Hence in the present study, we relied on the measures of CA used in the prior studies Chandler and Hanks (1994) and Kaya (2015). Five items were used to measure the differentiation based advantage while three items were used for the cost leadership based advantage.

All the variables were measured by using 5 point likert scales. ES and IC were measured by scales representing: strongly disagree $=1$, disagree $=2$, neutral $=3$, agree $=$ 4 and strongly agree $=5$. NVP was measured with scale represents; extremely declined $=1$, declined $=2$, average $=3$, improved $=4$ and extremely improved $=5$.

\subsection{Control variables}

Firm's size plays an active role in its performance as compared to other characteristics of enterprises and strategies (Blackburn, Hart, \& Wainwright, 2013). Newly established firms need to put more struggles for survival and growth as compared to older and large firms (Hamilton, 2012). Studies have recommended the age, industry, 
and size of firms to be controlled in SMEs studies (Shirokova et al., 2013; Wiklund $\&$ Shepherd, 2005). In the present study, size of firms, the age of firms and nature of industry are used as control variables. Since nature of the industry is a categorical variable, thus we created a dummy variable for each group of firms i.e. manufacturing, trading, and services and performed ANOVA in SPSS to check if the nature of the industry has a significant influence. The results indicated that there is no significant difference between the groups, which reveals that industry being a control variable has no significant role in the model. So we dropped this variable from further analysis. While the final regression analysis indicated that size and age of firms have a significant influence on NVP.

\subsection{Demographic of the firms}

Table 3 shows the demographic characteristics of the firms. 62 firms have employees from 20 to 50,83 have employees from 51 to 100 as well as 82 firms were having 101 to 250 employees. 63 firms have started a business since last 1 to 3 years or less, 90 firms started their operation during last 4 to 7 years while 74 firms were operated in last 8 to 10 years. In this study there were 115 manufacturing firms, 71 trading and 41 services firms participated in the survey with $(50.7 \%, 31.3 \%$ \& $18.1 \%)$ respectively.

Table 3: Demographic Profile of the Firms

\begin{tabular}{|c|c|c|}
\hline Description & Out of total & Percentage \\
\hline Size of firms & & 27.3 \\
\hline $10-50$ employees & 62 & 36.6 \\
\hline $51-100$ employees & 83 & 36.1 \\
\hline $101-250$ employees & 82 & \\
\hline Age of firms & & 27.8 \\
\hline 1 to 3 years & 63 & 39.6 \\
\hline 4 to 7 years & 90 & 32.6 \\
\hline 8 to 10 years & 74 & 50.7 \\
\hline Nature of industry & & 31.3 \\
\hline Manufacturing & 115 & 18.1 \\
\hline Trading & 71 & 100 \\
\hline Services & 41 & \\
\hline N & 227 & \\
\hline
\end{tabular}




\section{Data Analysis and Results}

\subsection{Interview results}

We conducted face to face interview with 17 entrepreneurs to confirm the validity of the model and to explore more fruitful insights. The interview helped us to elaborate and confirm the relationship between IC, ES, and NVP. We asked questions such as:

1. What do you mean by a firm performance?

2. What are the factors inside the organization that have a significant influence on the firm performance?

3. Can you tell us what kinds of things you think about when you hear the term intellectual capital?

4. Can you tell us what entrepreneurial strategy (innovative, risk-taking \& proactive) you follow?

5. What do you think as acompetitive advantage of your firm?

6. How intellectual capital and entrepreneurial strategy influence competitive advantage and firm's performance?

Ans.1: Thirteen entrepreneurs termed profit, sales growth, and customer satisfaction as firm's performance while the rest four entrepreneurs considered a competitive position over counterparts as a firm performance. A few entrepreneurs were overlapping CA and performance but not significantly.

Ans.2: Entrepreneurs suggested several internal factors that influence firm's performance. Six entrepreneurs suggested the financial capital, four suggested modern technology, five suggested competent employees and the remaining ones suggested innovative strategies.

Ans.3: Nine entrepreneurs stated that the skilled employees and managers, organizational resources and reputation are the major elements of IC for the firms. Five entrepreneurs said that all the intangible resources of firms are IC for them. However, three entrepreneurs considered different types of organization assets as IC.

Ans.4: Nine entrepreneurs favored innovative strategy, three favored risk-taking and the rest of the five entrepreneurs were likely to use proactive strategy.

Ans.5: Eleven entrepreneurs said that a higher position in the market over competitors is a competitive advantage and six entrepreneurs said that the unique 
resources that are not possessed by competitors are CA for them.

Ans.6: In this question, we narrowed the main theme to get specific objectives. Ten entrepreneurs said that IC helped them to gain CA and firms' performance and seven entrepreneurs relied on ES.

Thus, we found little bit differences between survey and interview results but we argue that there is no significant difference between the outputs. So, we claim that Pakistani entrepreneurs rely on IC and ES to gain CA and superior performance.

\subsection{Survey results}

Before testing the hypotheses, we performed several screening tests including normality test and variance inflation factor (VIF) test etc. to derive more fruitful results.

To assess the data normality, we performed skewness and kurtosis test in SPSS. The results indicated that the data are normal as the skewness and kurtosis values of each construct found in the accepted range \pm 2 recommended by (George \& Mallery, 2010). In addition, IC has mean value 3.16 and $S D$ is 0.47 , ES has mean value 3.21 and $\mathrm{SD}$ is 0.80 , CA has mean value 3.70 and $\mathrm{SD}$ is 0.75 and NVP has mean value 3.51 and SD 0.53 respectively.

Table 4: Mean, S.D and Normality

\begin{tabular}{|c|c|c|c|c|}
\hline Constructs & Mean & Std. Deviation & Skewness & Kurtosis \\
\hline Intellectual capital & 3.1648 & 0.46951 & 0.456 & -0.102 \\
\hline Entrepreneurial strategy & 3.2148 & 0.80470 & 0.205 & -1.537 \\
\hline Competitive advantage & 3.6905 & 0.74637 & 0.484 & -1.112 \\
\hline New Venture Performance & 3.5141 & 0.53063 & 0.264 & -1.577 \\
\hline
\end{tabular}

\subsubsection{Multicollinearity}

The existence of multicollinearity in the data describes that the variance explained by a specific IV in the DV is overlapping with each other (when the other IVs tested in a specific model) thus the IV is not explaining an exclusive variance. We performed VIF for IC, ES and CA on NVP and ran a multivariate regression test. Our results indicated that there is no multicollinearity issue in the data and each variable explains a unique variance in NVP. Following are the rules of thumb for the VIF:

a. VIF $<3$; no problem, considered good.

b. VIF > 3; maybe potential problem 
c. VIF > 5; very likely problem

d. VIF > 10; definitely have problem

The results presented in Table 5 indicate that all the cut off values of VIF are below 10 as recommended by (Hair, Black, Babin, \& Anderson, 2010) and the tolerance values for all the factors are above 0.10 and closed to 1.0 indicate good results (O’Brien, 2005).

Table 5: Variance Inflation Factors

\begin{tabular}{|c|c|c|}
\hline \multirow{2}{*}{} & \multicolumn{2}{|c|}{ New venture performance } \\
\cline { 2 - 3 } & \multicolumn{2}{|c|}{ Collinearity statistics } \\
\hline Independent variables & Tolerance & VIF \\
\hline Intellectual capital & 0.882 & 1.134 \\
\hline Entrepreneurial strategy & 0.916 & 1.092 \\
\hline Competitive advantage & 0.814 & 1.229 \\
\hline
\end{tabular}

\subsubsection{Reliability}

In order to check the quality of "being trustworthy" collected data, Cronbach's Alpha was used. Reliability value greater than $(0.70)$ is considered as good for trustworthiness measures and indicates an adequate internal consistency (Nunnally \& Bernstein, 1994). Table 6 shows the reliability values for all the variables which are greater than (0.70) claimed to be reliable results.

Table 6: Reliability, Mean and S.D of Variables

\begin{tabular}{|c|c|c|}
\hline Variables & No. of items & Cronbach's Alpha \\
\hline Intellectual capital & 6 & 0.76 \\
\hline Entrepreneurial strategy & 9 & 0.87 \\
\hline Competitive advantage & 8 & 0.74 \\
\hline New venture performance & 10 & 0.91 \\
\hline
\end{tabular}

\subsubsection{Correlation}

The correlation results depict earlier support to the proposed hypotheses of the study. The Pearson correlation results indicate (see Table 7) that IC has a significant positive relationship with NVP $(r=0.28, p<0.01)$, a significant positive relationship between ES and NVP $(r=0.64, p<0.01)$ and a significant positive relationship between CA and NVP $(r=0.49, p<0.01)$. Similarly, there is a significant positive relationship between IC and CA $(r=0.35, p<0.01)$ as well as a significant positive 
relationship between ES and NVP $(r=0.29, \mathrm{p}<0.01)$. The correlation values between all the factors less than 0.80 indicate that there is no multicollinearity issue (Jalali, Jaafar, \& Ramayah, 2014).

Table 7: Correlation Coefficients

\begin{tabular}{|c|c|c|c|c|c|c|}
\hline & 1 & 2 & 3 & 4 & 5 & 6 \\
\hline Size of firms & - & & & & & \\
\hline Age of firms & $0.481^{* *}$ & - & & & & \\
\hline Intellectual capital & 0.088 & $0.180^{* *}$ & - & & & \\
\hline Entrepreneurial strategy & $0.260^{* *}$ & $0.441^{* *}$ & 0.084 & - & & \\
\hline Competitive advantage & $0.245^{* *}$ & $0.312^{* *}$ & $0.344^{* *}$ & $0.290^{* *}$ & - & \\
\hline New venture performance & $0.490^{* *}$ & $0.641^{* *}$ & $0.277^{* *}$ & $0.644^{* *}$ & $0.492^{* *}$ & - \\
\hline
\end{tabular}

${ }^{* *}$ Correlation is significant at the 0.01 level (2-tailed).

\subsubsection{Test for mediation}

In this study, we followed the mediation steps suggested by Baron and Kenny (1986) and performed a separate test for each hypothesis to gain more distinctive insights and to avoid overlapping in outputs. Thus in the step 1, the impact of IC and ES was checked on NVP and found significant positive values $(\beta=0.188, p<0.05$ and $\beta=0.288, p<0.05$ ) simultaneously. Table 8 shows results about the influence of IC on NVP and Table 9 shows the influence of ES on NVP respectively. $\mathrm{R}^{2}$ values indicate that $48.1 \%$ variance can be explained by IC and $60.7 \%$ variance by ES in NVP in presence of age and size of firms as control variables. So H1 and H2 were supported on the basis of the study results and this step allowed us to go ahead.

In the step 2, we checked the impact of IC and ES on CA and also found significant positive values $(\beta=0.472, p<0.05$ and $\beta=0.169, p<0.05)$ simultaneously. The influence of IC on CA is presented in Table 10 and the influence of ES on CA has shown in Table 11 respectively. $\mathrm{R}^{2}$ indicates that $19.5 \%$ variance can be explained by IC and $13.6 \%$ variance can be explained by ES in CA when controlled for age and size of firms. So, $\mathrm{H} 3$ and $\mathrm{H} 4$ also supported by current results and suggested to go for the next step.

In step 3, we checked the impact of CA on NVP and the results derived from this step (see Table 12) also found significant and positive $(\square=0.215, \mathrm{p}<0.05)$ which supported $\mathrm{H} 5 . \mathrm{R}^{2}$ indicates that $53.5 \%$ variation can be explained by CA in NVP in presence of age and size of firms as control variables. The overall model summary values were significant in all the three steps. Hence, these three steps confirmed 
that CA mediates the relationship between IC and NVP as well as between ES and NVP. Thus in the next step, we checked either CA fully mediates or plays a partial mediating role.

\subsubsection{Tests for partial or full mediation}

Table 13 and Table 14 depict major results, either CA fully or partially mediates the relationships between IC-NVP and ES-NVP. In the first step of table 13, we entered two control variables, age and size of the firms, in the second step, we entered IC (independent variable) and in the third step, we entered CA (mediator). The impact of these variables was checked on NVP (dependent variable). According to the step

Table 8: Intellectual Capital and New Venture Performance

\begin{tabular}{|c|c|c|c|c|c|c|c|c|}
\hline \multirow[b]{2}{*}{ Model } & & \multicolumn{2}{|c|}{$\begin{array}{l}\text { Unstandardized } \\
\text { coefficients }\end{array}$} & \multirow{2}{*}{$\begin{array}{c}\text { Standardized } \\
\text { coefficients }\end{array}$} & \multirow[b]{2}{*}{$\mathrm{T}$} & \multirow[b]{2}{*}{ Sig. } & \multirow[b]{2}{*}{$\mathrm{R}^{2}$} & \multirow[b]{2}{*}{$\Delta \mathrm{R}^{2}$} \\
\hline & & B & S.E & & & & & \\
\hline \multicolumn{9}{|l|}{ Step 1} \\
\hline \multicolumn{2}{|c|}{ Size of firms } & 0.158 & 0.038 & 0.236 & 4.194 & 0.000 & & \\
\hline \multicolumn{2}{|c|}{ Age of firms } & 0.360 & 0.038 & 0.527 & 9.365 & 0.000 & $0.454^{* * *}$ & $0.454^{* * *}$ \\
\hline \multicolumn{9}{|l|}{ Step 2} \\
\hline \multicolumn{2}{|c|}{ Size of firms } & 0.158 & 0.037 & 0.236 & 4.287 & 0.000 & & \\
\hline \multicolumn{2}{|c|}{ Age of firms } & 0.340 & 0.038 & 0.498 & 8.928 & 0.000 & & \\
\hline \multicolumn{2}{|c|}{ Intellectual capital } & 0.188 & 0.055 & 0.167 & 3.400 & 0.001 & $0.481^{* * *}$ & $0.027^{* * *}$ \\
\hline
\end{tabular}

Table 9: Entrepreneurial Strategy and New Venture Performance

\begin{tabular}{|c|c|c|c|c|c|c|c|c|}
\hline \multirow[b]{2}{*}{ Model } & & \multicolumn{2}{|c|}{$\begin{array}{l}\text { Unstandardized } \\
\text { coefficients }\end{array}$} & \multirow{2}{*}{$\begin{array}{c}\text { Standardized } \\
\text { coefficients }\end{array}$} & \multirow[b]{2}{*}{$\mathrm{T}$} & \multirow[b]{2}{*}{ Sig. } & \multirow[b]{2}{*}{$\mathrm{R}^{2}$} & \multirow[b]{2}{*}{$\Delta \mathrm{R}^{2}$} \\
\hline & & B & S.E & & & & & \\
\hline \multicolumn{9}{|l|}{ Step 1} \\
\hline \multicolumn{2}{|c|}{ Size of firms } & 0.158 & 0.038 & 0.236 & 4.194 & 0.000 & & \\
\hline \multicolumn{2}{|c|}{ Age of firms } & 0.360 & 0.038 & 0.527 & 9.365 & 0.000 & $0.454^{* * *}$ & $0.454^{* * *}$ \\
\hline \multicolumn{9}{|l|}{ Step 2} \\
\hline \multicolumn{2}{|c|}{ Size of firms } & 0.140 & 0.032 & 0.209 & 4.364 & 0.000 & & \\
\hline \multicolumn{2}{|c|}{ Age of firms } & 0.237 & 0.035 & 0.348 & 6.731 & 0.000 & & \\
\hline \multicolumn{2}{|c|}{$\begin{array}{l}\text { Entrepreneurial } \\
\text { strategy }\end{array}$} & 0.288 & 0.031 & 0.437 & 9.313 & 0.000 & $0.607^{* * *}$ & $0.153^{* * *}$ \\
\hline
\end{tabular}


Table 10: Intellectual Capital and Competitive Advantage

\begin{tabular}{|c|c|c|c|c|c|c|c|}
\hline \multirow[b]{2}{*}{ Model } & & $\begin{array}{c}\text { Unstandardized } \\
\text { coefficients }\end{array}$ & \multirow{2}{*}{$\begin{array}{c}\text { Standardized } \\
\text { coefficients } \\
\text { Beta } \\
\end{array}$} & \multirow[b]{2}{*}{$\mathrm{T}$} & \multirow[b]{2}{*}{ Sig. } & \multirow[b]{2}{*}{$\mathrm{R}^{2}$} & \multirow[b]{2}{*}{$\Delta \mathrm{R}^{2}$} \\
\hline & & S.E & & & & & \\
\hline \multicolumn{8}{|l|}{ Step 1} \\
\hline \multicolumn{2}{|c|}{ Size of firms } & 0.068 & 0.124 & 1.720 & 0.087 & & \\
\hline \multicolumn{2}{|c|}{ Age of firms } & 0.069 & 0.253 & 3.516 & 0.001 & $0.109^{* * *}$ & $0.109^{* * *}$ \\
\hline \multicolumn{8}{|l|}{ Step 2} \\
\hline \multicolumn{2}{|c|}{ Size of firms } & 0.064 & 0.123 & 1.797 & 0.074 & & \\
\hline \multicolumn{2}{|c|}{ Age of firms } & 0.067 & 0.200 & 2.878 & 0.004 & & \\
\hline \multicolumn{2}{|c|}{ Intellectual capital } & 0.097 & 0.297 & 4.860 & 0.000 & $0.195^{* * *}$ & $0.085^{* * *}$ \\
\hline
\end{tabular}

Table 11: Entrepreneurial Strategy and New Venture Performancee

\begin{tabular}{|c|c|c|c|c|c|c|c|c|}
\hline \multirow[b]{2}{*}{ Model } & & \multicolumn{2}{|c|}{$\begin{array}{l}\text { Unstandardized } \\
\text { coefficients }\end{array}$} & \multirow{2}{*}{$\begin{array}{c}\begin{array}{c}\text { Standardized } \\
\text { coefficients }\end{array} \\
\text { Beta }\end{array}$} & \multirow[b]{2}{*}{$\mathrm{T}$} & \multirow[b]{2}{*}{ Sig. } & \multirow[b]{2}{*}{$\mathrm{R}^{2}$} & \multirow[b]{2}{*}{$\Delta \mathrm{R}^{2}$} \\
\hline & & B & S.E & & & & & \\
\hline \multicolumn{9}{|l|}{ Step 1} \\
\hline \multicolumn{2}{|c|}{ Size of firms } & 0.116 & 0.068 & 0.124 & 1.720 & 0.087 & & \\
\hline \multicolumn{2}{|c|}{ Age of firms } & 0.243 & 0.069 & 0.253 & 3.516 & 0.001 & $0.109^{* * *}$ & $0.109^{* * *}$ \\
\hline \multicolumn{9}{|l|}{ Step 2} \\
\hline \multicolumn{2}{|c|}{ Size of firms } & 0.106 & 0.067 & 0.113 & 1.582 & 0.115 & & \\
\hline \multicolumn{2}{|c|}{ Age of firms } & 0.171 & 0.074 & 0.178 & 2.326 & 0.021 & & \\
\hline \multicolumn{2}{|c|}{$\begin{array}{l}\text { Entrepreneurial } \\
\text { strategy }\end{array}$} & 0.169 & 0.064 & 0.182 & 2.614 & 0.010 & $0.136^{* * *}$ & $0.026^{* * *}$ \\
\hline
\end{tabular}

Table 12: Competitive Advantage and New Venture Performance

\begin{tabular}{|c|c|c|c|c|c|c|c|}
\hline \multirow[b]{2}{*}{ Model } & \multicolumn{2}{|c|}{$\begin{array}{l}\text { Unstandardized } \\
\text { coefficients }\end{array}$} & \multirow{2}{*}{$\begin{array}{c}\begin{array}{c}\text { Standardized } \\
\text { coefficients }\end{array} \\
\text { Beta }\end{array}$} & \multirow[b]{2}{*}{$\mathrm{T}$} & \multirow[b]{2}{*}{ Sig. } & \multirow[b]{2}{*}{$\mathrm{R}^{2}$} & \multirow[b]{2}{*}{$\Delta \mathrm{R}^{2}$} \\
\hline & B & S.E & & & & & \\
\hline \multicolumn{8}{|l|}{ Step 1} \\
\hline Size of firms & 0.158 & 0.038 & 0.236 & 4.194 & 0.000 & & \\
\hline Age of firms & 0.360 & 0.038 & 0.527 & 9.365 & 0.000 & $0.454^{* * *}$ & $0.454^{* * *}$ \\
\hline \multicolumn{8}{|l|}{ Step 2} \\
\hline Size of firms & 0.133 & 0.035 & 0.199 & 3.793 & 0.000 & & \\
\hline Age of firms & 0.308 & 0.037 & 0.451 & 8.432 & 0.000 & & \\
\hline Competitive advantage & 0.215 & 0.034 & 0.303 & 6.256 & 0.000 & $0.535^{* * *}$ & $0.082^{* * *}$ \\
\hline
\end{tabular}


3 of Table 13, CA fully mediates the relationship between IC and NVP. It can be interpreted as, in the presence of CA, IC influences NVP insignificantly. For instance, the influence of CA is significant and positive on $\operatorname{NVP}(\beta=0.196, p<0.05)$ while the value for IC reversed into insignificant $(\beta=0.096, \mathrm{P}>0.05)$. This result confirmed that CA fully mediates the relationship between IC and NVP which supported H6. The $\mathrm{R}^{2}$ value indicates that $53.4 \%$ of the variance in NVP, explained by IC and CA in the presence of age and size of the firms as control variables.

The same test was performed for checking the full or a partial mediating role of CA between ES and NVP. The results indicated (see Table 14-step 3) that CA partially mediates the relationship between ES and NVP. The influence of ES remained significant on NVP $(\beta=0.259, \mathrm{P}<0.05)$ after using CA as mediator. The results partially supported $\mathrm{H} 7$ and indicate that CA partially mediates the relationship between ES and NVP. The value of $\mathrm{R}^{2}$ indicates that $65.6 \%$ variance explained by ES with the help of CA in NVP.

Table 13: Mediating Role of Competitive Advantage between Intellectual Capital and New Venture Performance

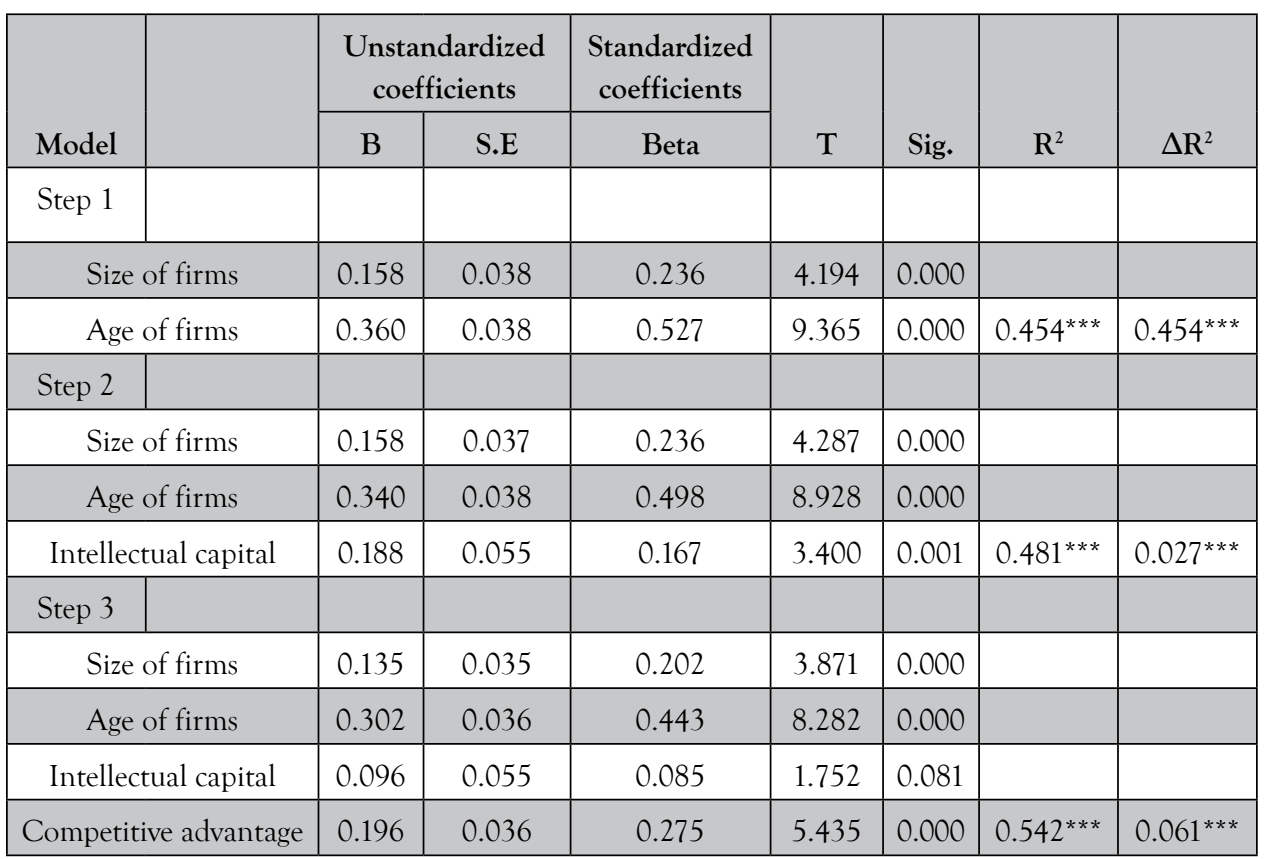


Table 14: Mediating Role of Competitive Advantage between Entrepreneurial Strategy and New Venture Performance

\begin{tabular}{|c|c|c|c|c|c|c|c|c|}
\hline \multirow[b]{2}{*}{ Model } & & \multicolumn{2}{|c|}{$\begin{array}{c}\text { Unstandardized } \\
\text { coefficients }\end{array}$} & \multirow{2}{*}{$\begin{array}{c}\begin{array}{c}\text { Standardized } \\
\text { coefficients }\end{array} \\
\text { Beta }\end{array}$} & \multirow[b]{2}{*}{$\mathrm{T}$} & \multirow[b]{2}{*}{ Sig. } & \multirow[b]{2}{*}{$\mathrm{R}^{2}$} & \multirow[b]{2}{*}{$\Delta \mathrm{R}^{2}$} \\
\hline & & B & S.E & & & & & \\
\hline \multicolumn{9}{|l|}{ Step 1} \\
\hline \multicolumn{2}{|c|}{ Size of firms } & 0.158 & 0.038 & 0.236 & 4.194 & 0.000 & & \\
\hline \multicolumn{2}{|c|}{ Age of firms } & 0.360 & 0.038 & 0.527 & 9.365 & 0.000 & $0.454^{* * *}$ & $0.454^{* * *}$ \\
\hline \multicolumn{9}{|l|}{ Step 2} \\
\hline \multicolumn{2}{|c|}{ Size of firms } & 0.140 & 0.032 & 0.209 & 4.364 & 0.000 & & \\
\hline \multicolumn{2}{|c|}{ Age of firms } & 0.237 & 0.035 & 0.348 & 6.731 & 0.000 & & \\
\hline \multicolumn{2}{|c|}{$\begin{array}{c}\text { Entrepreneurial } \\
\text { strategy }\end{array}$} & 0.288 & 0.031 & 0.437 & 9.313 & 0.000 & $0.607^{* * *}$ & $0.153^{* * *}$ \\
\hline \multicolumn{9}{|l|}{ Step 3} \\
\hline \multicolumn{2}{|c|}{ Size of firms } & 0.122 & 0.030 & 0.183 & 4.036 & 0.000 & & \\
\hline \multicolumn{2}{|c|}{ Age of firms } & 0.208 & 0.033 & 0.305 & 6.228 & 0.000 & & \\
\hline \multicolumn{2}{|c|}{$\begin{array}{c}\text { Entrepreneurial } \\
\text { strategy }\end{array}$} & 0.259 & 0.029 & 0.393 & 8.813 & 0.000 & & \\
\hline \multicolumn{2}{|c|}{ Competitive advantage } & 0.169 & 0.030 & 0.238 & 5.624 & 0.000 & $0.656^{* * *}$ & $0.049^{* * *}$ \\
\hline
\end{tabular}

\section{Discussion}

The results of the study reveal that Pakistani SMEs are engaged in developing IC, ES, and CA to gain superior performance in the markets. Recently CA and firms' performance are focused extensively in strategic management research. But the majority of studies are conducted in developed economies and SMEs in developing countries are underemphasized. However, SMEs in developing countries have a key contribution to the nations' GDP (Khattak et al., 2011; Rahayu \& Day, 2015). Hence, this paper confirms and extends the results of the previous studies by adding new evidence from a developing country Pakistan.

This study concluded that IC (human capital, structure capital and relational capital) has a positive impact on NVP. The results confirmed H1 and depicted the same results as scrutinized by previous studies such as, Tandon et al. (2016) illustrated that there is a significant positive relationship between IC and NVP. Therefore, successful companies invest their resources in building IC. Similarly, H3 is also supported in this study as derived by a recent study of Cleary and Quinn (2016) who revealed that SMEs have limited resources and opportunities and they cannot invest 
in risky and big projects. Therefore, they seek CA and superior performance through intangible resources such as IC. Tandon et al. (2016) indicate that firms can achieve CA by efficient use of IC. Hence, this study supported and proved the results of the previous studies.

ES has received a considerable attention in newly established firms. In this study, the results scrutinized that ES has a positive and significant impact on firms' performance and $\mathrm{CA}$ which supported $\mathrm{H} 2$ and $\mathrm{H} 4$ of the study respectively. The results are also parallel in the line with previous studies where, Demil et al. (2015) argued that in a dynamic environment, innovative ES has more significance in comparison with traditional strategies to gain CA and to improve NVP. Obeng et al. (2014) also suggested that enterprises' strategies based on recent innovative ideas have a significant positive impact on NVP. Meyer and Heppard (2000) resulted that ES is based on entrepreneurial mindsets and behaviors which investigate a market demand persistently. As results of new products development and innovation, firms lead toward higher profitability. Herrera (2015) illustrated that the firms' strategic behavior captures innovative ideas which create wealth for firms.

In the present study, it is argued that CA has a significant positive impact on NVP. Thus, $\mathrm{H} 5$ of the present study is supported on the basis of the selected sample. The same significant and positive results were deduced from previous literature. For instance, Palmer et al. (2015) elucidated that firms analyze different markets based on their innovative strategy to gain CA because they believe that CA can significantly contribute firm's performance. Similarly, Herzallah et al. (2014) and Ma (2000) resulted that CA has a significant positive association with firms' performance.

CA not only influences firm's performance but it also mediates the relationship between other factors and firms performance. For instance, Jain et al. (2017) and Nardo and Veltri (2014) scrutinized that CA fully mediates the relationship between IC and a firm's performance. Hence the same results are found in the present study and confirmed $\mathrm{H} 6$ of the study. While studies also argued that CA mediates the relationship between entrepreneurial orientation and a firm's performance. As Lechner and Gudmunsson (2014) and Mahmood and Hanafi (2013) indicated that competitive strategy mediates the relationship between entrepreneurial orientation and a firm's performance. Consistent with Kianto et al. (2013) who resulted that CA is a significant mediator between IC and firms performance. The same findings has found in this paper and supported $\mathrm{H} 7$ of the study.

Our study reveals that newly established SMEs in Pakistan build their CA through IC followed by ES. Pakistani SMEs face an emerging competition, hence they look for less expensive sources to enhance their performance and survival in the market. 
In addition, SMEs in the country have lack of resources and government supports, thus firms search for alternative ways to improve revenue. In this sense, IC and ES are the major factors that can boost a firm's performance in dynamic markets.

\subsection{Contributions of the study}

This paper has two major contributions to existing literature of IC, ES, and NVP in respect to RBVT. For instance, RBVT suggests that firms' internal capabilities have more influence on performance as compared to external capabilities (Barney, 1991). Based on RBVT, IC and ES may be considered as distinctive intangible resources that every firm integrates routinely in order to achieve a sustainable CA and superior performance. Hence, this study supports the main theme of RBVT by applying a mix method approach. On the other side, this study contributes to major determinants of newly established ventures. For instance, Khawaja (2006- CEO of SMEDA) supposed that $19 \%$ of newly established ventures fail within first five years and only $4 \%$ of firms survive up to 25 years in Pakistan, this can be deemed a higher failure rate. Nonetheless, the majority of the studies of this nature have ignored the determinants of success and failure of newly established ventures. In addition, newly established ventures have lack of financial and other physical resources in comparison with mature firms, they might mainly focus on intangible resource and capabilities to make ensure their survival in a dynamic market. Hence, this study provides useful insights for potential researchers to conduct further studies on underemphasized factors that contribute big part toward the success and survival of newly established ventures.

\subsection{Im plications for practice}

This study suggests several significant implications for owners and managers of newly established ventures. Our findings reveal that CA has a direct and significant impact on NVP as well as it mediates the relationship between IC and NVP and also mediates the relationship between ES and NVP. The results give signals to owners and managers who compete in dynamic markets and face shortage of resources. The findings of the study reveal that SMEs might give proper attention to their CA either aimed through cost leadership or differentiation. IC works as an intangible source to achieve CA and superior performance. Firms may focus on their IC such as human, relational and structural capital. Similarly, ES also plays a key role that intimates owners and managers to be entrepreneurial minded and must be aware of dynamic market changes to obtain CA and higher profitability. To some extent, the study highlights the importance of intangible and less costly factors in the success of SMEs, thus SMEs can be cautious about investment in risky projects and assets. These arguments may help newly established firms to give sufficient attention to their internal capabilities and strategic postures. 
The overall results implicate that owners and managers of the new ventures are required to put extreme focus on the improvement of IC efficiency followed by ES. New ventures encounter lots of internal problems as well as they face pressure from external competitors which attenuate their movement toward growth. But these ventures have to put their efforts toward growth and success which can be strengthened through IC and ES.

In addition, SMEDA might play an active role in supporting the firms in the development of intellectual capabilities and a strategic posture by arranging seminars, training, and workshops or free courses to enrich the progress of industrial sectors. For instance, Gul and Nouman (2009) suggested that there is a great need for private and government organizations to support SMEs regarding innovation in order to enhance the sustainability of the industrial sector. Because healthy industrial sector cannot be underestimated in productivity and a higher standard of living in emerging markets such as Pakistan (Shah et al., 2011).

\subsection{Limitations and directions for future research}

Despite several strengths, this study is not free of limitations, for example, the analysis shows simple statistical tests, in addition to these tests, some others tests specifically, structural equation modeling (SEM) can be used in future to obtain more reliable and generalizable results. The small size of the sample is also considered as a limitation of the study.

It is suggested for future researchers to overcome the limitations of the study which can be beneficial for researchers and entrepreneurs. Further studies can check the association of these factors in some other developing countries. It will be better to add some more possible variables such as market knowledge, environmental factors etc., to gain more realistic results. We have interviewed a small group of entrepreneurs to confirm our model, future studies can conduct more comprehensive interviews to articulate results in a better way.

Huo et al. (2014) suggested that competitive strategy moderates the relationship between supply chain management and firms' performance. Each competitive strategy as a moderator can be checked between each dimension of IC and firm's performance.

In addition, this study highlighted that internal capabilities contribute to the survival of new ventures; in contrast, further studies can be conducted to explore the causes of new ventures failure. Moreover, comparative studies on emerging and developed economies will provide more fruitful insights. 


\section{Conclusion}

Using a mix method approach, data for this study were collected through a structured questionnaire from 227 registered ventures and interviewed 17 entrepreneurs in the central cities of Pakistan (Rawalpindi \& Islamabad). The results of interview and survey show a significant relationship and support the model. The findings indicate that CA fully mediates the relationship between IC and NVP as well as it plays a partial mediating role between ES and NVP.

\section{References}

Agostini, L., Nosella, A., \& Filippini, R. (2017). Does intellectual capital allow improving innovation performance? A quantitative analysis in the SME context. Journal of Intellectual Capital, 18(2), 400-418.

Ahmad, M., \& Ahmed, N. (2016). Testing the relationship between intellectual capital and a firm's performance: An empirical investigation regarding financial industries of Pakistan. International Journal of Learning and Intellectual Capital, 13(2-3), 250-272.

Akhtar, C. S., Ismail, K., Hussain, J., \& Umair-ur-Rehman, M. (2015). Investigating the moderating effect of family on the relationship between entrepreneurial orientation and success of enterprise: Case of Pakistani manufacturing SMEs. International Journal of Entrepreneurship and Small Business, 26(2), 233-247.

Anwar, M. (2018). Business model innovation and SMEs performance - Does competitive advantage mediate? International Journal of Innovation Management, https://doi.org/10.1142/S1363919618500573

Baker, M. D., \& Maner, J. K. (2008). Risk-taking as a situationally sensitive male mating strategy. Evolution and Human Behavior, 29(6), 391-395.

Barney, J. (1991). Firm resources and sustained competitive advantage. Journal of Management, 17(1), 99-120.

Baron, R. M., \& Kenny, D. A. (1986). The moderator-mediator variable distinction in social psychological research: Conceptual, strategic, and statistical considerations. Journal of Personality and Social Psychology, 51(6), 1173.

Berzkalne, I., \& Zelgalve, E. (2014). Intellectual capital and company value. Procedia-Social and Behavioral Sciences, 110, 887-896.

Biggadike, E. R. (1979). Corporate diversification: Entry, strategy, and performance. Cambridge, MA: Harvard University Press.

Blackburn, R. A., Hart, M., \& Wainwright, T. (2013). Small business performance: Business, strategy and owner-manager characteristics. Journal of Small Business and Enterprise Development, 20(1), 8-27. 
Brizek, M. G. (2014). Explaining corporate entrepreneurship: A contemporary literature investigation. Journal of Management and Marketing Research, 14, 1.

Brooking, A. (1996). Intellectual capital, core asset for the Third Millenium. London: Europe.

Brouthers, K. D., Nakos, G., \& Dimitratos, P. (2015). SME entrepreneurial orientation, international performance, and the moderating role of strategic alliances. Entrepreneurship Theory and Practice, 39(5), 1161-1187.

Burpitt, W., \& Fowler, S. (2007). Entrepreneurial strategies in a declining industry. Journal of Small Business Strategy, 18(1), 69.

Cater, T., \& Pucko, D. (2005). How competitive advantage influences firm performance: The case of Slovenian firms. Economic and Business Review for Central and South-Eastern Europe, 7(2), 119.

Chahal, H., \& Bakshi, P. (2015). Examining intellectual capital and competitive advantage relationship: Role of innovation and organizational learning. International Journal of Bank Marketing, 33(3), 376-399.

Chandler, G. N., \& Hanks, S. H. (1994). Market attractiveness, resource-based capabilities, venture strategies, and venture performance. Journal of Business Venturing, 9(4), 331-349.

Chen, Y. S. (2008). The positive effect of green intellectual capital on competitive advantages of firms. Journal of Business Ethics, 77(3), 271-286.

Chrisman, J. J., Bauerschmidt, A., \& Hofer, C. W. (1998). The determinants of new venture performance: An extended model. Entrepreneurship Theory and Practice, 23, 5-30.

Cleary, P., \& Quinn, M. (2016). Intellectual capital and business performance: An exploratory study of the impact of cloud-based accounting and finance infrastructure. Journal of Intellectual Capital, 17(2), 255-278.

Covin, J. G., \& Slevin, D. P. (1989). Strategic management of small firms in hostile and benign environments. Strategic Management Journal, 10(1), 75-87.

Covin, J. G., \& Slevin, D. P. (1990). New venture strategic posture, structure, and performance: An industry life cycle analysis. Journal of Business Venturing, 5(2), 123-135.

Crossan, M. M., \& Apaydin, M. (2010). A multildimensional framework of organizational innovation: A systematic review of the literature. Journal of Management Studies, 47(6), 1154-1191.

Dana, L. P., \& Dana, T. E. (2005). Expanding the scope of methodologies used in entrepreneurship research. International Journal of Entrepreneurship and Small Business, 2(1), 79-88.

Day, G. S. (2014). An outside-in approach to resource-based theories. Journal of the Academy of Marketing Science, 42(1), 27-28.

Demil, B., Lecocq, X., Ricart, J. E., \& Zott, C. (2015). Introduction to the SEJ special issue on business 
models: Business models within the domain of strategic entrepreneurship. Strategic Entrepreneurship Journal, 9(1), 1-11.

Dibrell, C., Craig, J. B., \& Neubaum, D. O. (2014). Linking the formal strategic planning process, planning flexibility, and innovativeness to firm performance. Journal of Business Research, 67(9), 2000-2007.

Falbe, C. M., Dandridge, T. C., \& Kumar, A. (1999). The effect of organizational context on entrepreneurial strategies in franchising. Journal of Business Venturing, 14(1), 125-140.

George, D., \& Mallery, P. (2010). SPSS for Windows step by step. A simple study guide and reference (10. Baskı).

Gruber-Muecke, T., \& Hofer, K. M. (2015). Market orientation, entrepreneurial orientation and performance in emerging markets. International Journal of Emerging Markets, 10(3), 560-571.

Gul, S., \& Nouman, M. (2009). Innovation in Pakistan? SMES: Making the case for coupling model and looking beyond. Business $\mathcal{E}$ Economic Review, 1(1), 20-25.

Hair, J.F. Jr., Black, W.C., Babin, B.J., \& Anderson, R.E. (2010), Multivariate Data Analysis: A Global Perspective, Prentice Hall and Pearson, Upper Saddle River, NJ

Hamilton, R.T. (2012). How firms grow and the influence of size and age. International Small Business Journal, 30(6), 611-21.

Harris, R., \& Moffat, J. (2013). Intangible assets, absorbing knowledge and its impact on firm performance: Theory, measurement and policy implications. Contemporary Social Science, 8(3), 346-361.

Herrera, M. E. B. (2015). Creating competitive advantage by institutionalizing corporate social innovation. Journal of Business Research, 68(7), 1468-1474.

Herzallah, A. M., Gutiérrez-Gutiérrez, L., \& Munoz Rosas, J. F. (2014). Total quality management practices, competitive strategies and financial performance: The case of the Palestinian industrial SMEs. Total Quality Management $\mathcal{E}$ Business Excellence, 25(5-6), 635-649.

Hitt, M. A., Ireland, R. D., Camp, S. M., \& Sexton, D. L. (2001). Strategic entrepreneurship: Entrepreneurial strategies for wealth creation. Strategic Management Journal, 22(607), 479-491.

Hohenthal, J. (2006). Integrating qualitative and quantitative methods in research on international entrepreneurship. Journal of International Entrepreneurship, 4(4), 175-190.

Hormiga, E., Batista-Canino, R. M., \& Sánchez-Medina, A. (2011). The role of intellectual capital in the success of new ventures. International Entrepreneurship and Management Journal, 7(1), 71-92.

Hult, G. T. M., Hurley, R. F., \& Knight, G. A. (2004). Innovativeness: its antecedents and impact on business performance. Industrial Marketing Management, 33, 429-438.

Huo, B., Qi, Y., Wang, Z., \& Zhao, X. (2014). The impact of supply chain integration on firm perfor- 
mance: The moderating role of competitive strategy. Supply Chain Management: An International Journal, 19(4), 369-384.

Jain, P., Vyas, V., \& Roy, A. (2017). Exploring the mediating role of intellectual capital and competitive advantage on the relation between CSR and financial performance in SMEs. Social Responsibility Journal, 13(1).

Jalali, A., Jaafar, M., \& Ramayah, T. (2014). Entrepreneurial orientation and performance: The interaction effect of customer capital. World Journal of Entrepreneurship, Management and Sustainable Development, 10(1), 48-68.

Jick, T. D. (1979). Mixing qualitative and quantitative methods: Triangulation in action. Administrative Science Quarterly, 24(4), 602-611.

Jurczak, J. (2008). Intellectual capital measurement methods. Economics and organization of enterprise, 1(1), $37-45$.

Kantur, D. (2016). Strategic entrepreneurship: mediating the entrepreneurial orientation-performance link. Management Decision, 54(1), 24-43.

Kaya, N. (2015). Corporate entrepreneurship, generic competitive strategies, and firm performance in small and medium-sized enterprises. Procedia-Social and Behavioral Sciences, 207, 662-668.

Khalique, M., Bontis, N., Abdul Nassir bin Shaari, J., \& Hassan Md. Isa, A. (2015). Intellectual capital in small and medium enterprises in Pakistan. Journal of Intellectual Capital, 16(1), 224-238.

Khan, A. A., \& Jamal, W. (2013). Intellectual capital: Perception of public and private sector knowledge-based organizations in Pakistan. Business $\mathcal{E}$ Economic Review, 5(1), 29-52.

Khattak, J. K., Arslan, M., \& Umair, M. (2011). SMEs' export problems in Pakistan. E3 Journal of Business Management and Economics, 2(5), 192-199.

Khawaja, S. (2006). Unleashing the growth potential of SMEs in Pakistan through productivity enhancement. Pakistan Development Forum.

Kianto, A., Andreeva, T., \& Pavlov, Y. (2013). The impact of intellectual capital management on company competitiveness and financial performance. Knowledge Management Research EO Practice, 11(2), 112-122.

Lechner, C., \& Gudmundsson, S. V. (2014). Entrepreneurial orientation, firm strategy and small firm performance. International Small Business Journal, 32(1), 36-60.

Lonial, S. C., \& Carter, R. E. (2015). The impact of organizational orientations on medium and small firm performance: A resourcelbased perspective. Journal of Small Business Management, 53(1), 94-113.

Lumpkin, G. T., \& Dess, G. G. (1996). Clarifying the entrepreneurial orientation construct and linking it to performance. Academy of Management Review, 21(1), 135-172.

Lumpkin, G. T., \& Dess, G. G. (2001). Linking two dimensions of entrepreneurial orientation to 
firm performance: The moderating role of environment and industry life cycle. Journal of Business Venturing, 16(5), 429-451.

Ma, H. (2000). Competitive advantage and firm performance. Competitiveness Review: An International Business Journal, 10(2), 15-32.

Mahmood, R., \& Hanafi, N. (2013). Entrepreneurial orientation and business performance of women-owned small and medium enterprises in Malaysia: Competitive advantage as a mediator. International Journal of Business and Social Science, 4(1).

Majid, A., \& Yasir, M. (2017). Individual and work dynamics affecting the determinants of functional flexibility in SMEs: Evidence from Pakistan. Journal of Entrepreneurship in Emerging Economies, 9(2), 144-160.

Meyer, G. D., \& Heppard, K. A. (2000). Entrepreneurship as strategy: Competing on the entrepreneurial edge. Sage Publications.

Mintzberg, H. (1993). Structure in fives: Designing effective organizations. Prentice-Hall, Inc.

Moreno A., \& Casillas J. (2008). Entrepreneurial orientation and growths of SMEs: A causal model. Entrepreneurship Theory and Practice, 32(3), 507-528.

Muhammad, N. M. N., \& Ismail, M. K. A. (2009). Intellectual capital efficiency and firm's performance: Study on Malaysian financial sectors. International Journal of Economics and Finance, 1(2), 206.

Murray, J. A. (1984). A concept of IC. Strategic Management Journal, 5(1), 1-13.

Nardo, M. T., \& Veltri, S. (2014). On the plausibility of an integrated approach to disclose social and intangible issues. Social Responsibility Journal, 10(3), 416 - 435.

Ndofor, H. A., Sirmon, D. G., \& He, X. (2011). Firm resources, competitive actions and performance: Investigating a mediated model with evidence from the inlvitro diagnostics industry. Strategic Management Journal, 32(6), 640-657.

Nouman, M., Taj, A., \& Gul, S. (2017). The individual's influence on low-technology innovation: A critical realism based case study on North-West Pakistan's marble sector. Business $\mathcal{E}$ Economic Review, 9(1), 131-155.

Nunnally, J. C., \& Bernstein, I. H. (1994). The theory of measurement error. Psychometric Theory, 209-247.

O'Brien, M.G. (2005). MANOVA method for analyzing repeated-measures designs: An extensive primer. Psychological Bulletin, (97)2, 316-33.

Obeng, B. A., Robson, P., \& Haugh, H. (2014). Strategic entrepreneurship and small firm growth in Ghana. International Small Business Journal, 32(5), 501-524.

Palmer, J. C., Wright, R. E., \& Powers, J. B. (2015). Innovation and competitive advantage in small businesses: Effects of environments and business strategy. Journal of Small Business Strategy, 12(1), 30-41. 
Porter, M. E. (1980). Competitive strategy: Techniques for analyzing industries and competition. New York, 300.

Priem, RL. (2007). A consumer perspective on value creation. Academy of Management Review, 32(1), 219-235.

Prieto, I. M., \& Revilla, E. (2006). Learning capability and business performance: A non-financial and financial assessment. The Learning Organization, 13(2), 166-185.

Radaev, V. (2002). Entrepreneurial strategies and the structure of transaction costs in Russian business. Problems of Economic Transition, 44(12), 57-84.

Rahayu, R., \& Day, J. (2015). Determinant factors of E-commerce adoption by SMEs in Developing Country: Evidence from Indonesia. Procedia-Social and Behavioral Sciences, 195, 142-150.

Rossi, C., Cricelli, L., Grimaldi, M., \& Greco, M. (2016). The strategic assessment of intellectual capital assets: An application within Terradue Srl. Journal of Business Research, 69(5), 1598-1603.

Russell, R. D., \& Russell, C. J. (1992). An examination of the effects of organizational norms, organizational structure, and environmental uncertainty on IC. Journal of Management, 18(4), 639-656.

Saint-Onge, H. (1996). Tacit knowledge the key to the strategic alignment of intellectual capital. Planning Review, 24(2), 10-16.

Semrau, T., Ambos, T., \& Kraus, S. (2016). Entrepreneurial orientation and SME performance across societal cultures: An international study. Journal of Business Research, 69(5), 1928-1932.

Shah, A., Gul, S., \& Aziz, R. (2011). Problems facing the Hayatabad industrial estate and their implications on policy formulation. Business $\mathcal{E}$ Economic Review, 2(3), 164-174.

Shane S, Venkataraman S. (2000). The promise of entrepreneurship as a field of research. Academy of Management Review, 25, 217-226.

Shirokova, G., Vega, G., \& Sokolova, L. (2013). Performance of Russian SMEs: Exploration, exploitation and strategic entrepreneurship. Critical Perspectives on International Business, 9(1/2), 173-203.

Stam, W., \& Elfring, T. (2008). Entrepreneurial orientation and new venture performance: The moderating role of intra-and extraindustry social capital. Academy of Management Journal, 51(1), 97-111.

Su, Z., Guo, H., \& Sun, W. (2017). Exploration and firm performance: The Moderating impact of competitive strategy. British Journal of Management, 28(3), 357-371.

Sun, J., Yao, M., Zhang, W., Chen, Y., \& Liu, Y. (2016). Entrepreneurial environment, market-oriented strategy, and entrepreneurial performance: A study of Chinese automobile firms. Internet Research, 26(2), 546-562.

Tajeddini, K., \& Mueller, S. L. (2012). Corporate entrepreneurship in Switzerland: Evidence from a 
case study of Swiss watch manufacturers. International Entrepreneurship and Management Journal, 8(3), 355-372.

Talebi, K., Rezazadeh, A., \& Najmabadi, A. D. (2015). SME alliance performance: The impacts of alliance entrepreneurship, entrepreneurial orientation, and intellectual capital. International Journal of Entrepreneurship and Small Business, 24(2), 187-207.

Tandon, K., Purohit, H., \& Tandon, D. (2016). Measuring intellectual capital and its impact on financial performance: Empirical evidence from CNX Nifty Companies. Global Business Review, 17(4), 980-997.

Todericiu, R., \& Stlni], A. (2015). Intellectual Capital-The key for sustainable competitive advantage for the SME's Sector. Procedia Economics and Finance, 27, 676-681.

Wiklund, J., \& Shepherd, D. (2005). Entrepreneurial orientation and small business performance: A configurational approach. Journal of Business Venturing, 20(1), 71-91.

World Bank. (2017). Doing Business 2017: Equal Opportunity for All. Washington D.C.: World Bank.

Yaseen, S. G., Dajani, D., \& Hasan, Y. (2016). The impact of intellectual capital on the competitive advantage: Applied study in Jordanian telecommunication companies. Computers in Human Behavior, 62, 168-175.

Zahra, S., Hayton, J., Marcel, J., \& O’Neill, H. (2001). Fostering entrepreneurship during international expansion: Managing key challenges. European Management Journal, 19(4), 359-369. 
